\title{
AS MARCAS DA ANCESTRALIDADE NA ESCRITA DE AUTORES \\ CONTEMPORÂNEOS DAS LITERATURAS AFRICANAS DE LÍNGUA PORTUGUESA
}

JuREMa OLIVEIRA*

\section{RESUMO}

O presente trabalho propõe uma leitura crítica das marcas da ancestralidade nas narrativas africanas de língua portuguesa. O corpus escolhido para a análise compõe-se de Terra sonâmbula, de Mia Couto (1993); Momento de ilusão, de Fragata de Morais (2000); Mãe, materno mar e A morte do velho Kipacaça, ambos de Boaventura Cardoso (2001; 2004); Contos de morte, de Pepetela (2008); e As andorinhas, de Paulina Chiziane (2013). A tipologia de Leite (2008) sobre a noção de ancestralidade na obra A questão ancestral: África negra, bem como estudos sobre memória, oralidade e da área da Teoria da Literatura são usados para dar suporte à análise proposta neste estudo.

PAlaVRAS-ChAVE: África, ancestralidade, divindade, oralidade, memória e ficção.

Dentre as formulações apresentadas por Fabio Leite (2008), destacam-se duas: ancestrais de essência mítica (preexistente e divindades) e os ancestrais de essência histórica (ancestrais históricos) referentes a complexos civilizatórios específicos. As práticas relacionadas ao funeral começam imediatamente após o óbito, estágio em que se faz necessário caracterizar socialmente o término da existência humana, ao mesmo tempo em que se dá o processo de desintegração dos aspectos vitais que se encontram em desequilíbrio, pois

aona, 'corpo', ainda guarda certas características, Woa woe, o 'duplo', não abandonou completamente o corpo e o Ekala encontra-se em situação extremamente difícil, pois somente o tempo e a sociedade poderão auxiliá-lo a encaminhar-se em direção ao país dos

* Professora da Universidade Federal do Espírito Santo, Vitória, Espírito Santo, Brasil. E-mail: juremajoliveira@hotmail.com 
ancestrais, Ebolo, onde não penetrará a não ser após cumprida as cerimônias funerárias. (Leite, 2008, p. 105)

A concepção da existência para os Agni ${ }^{1}$ constitui-se por duas modalidades de Ekala. Uma está ligada à perspectiva de o sujeito tornar-se ancestral, o qual é definido como Ese Kpili, logo recebe um tratamento especial, um funeral completo. A outra modalidade de Ekala forma-se pelo Efewoa, que está destinado à reencarnação:

Os indivíduos Efewoa não têm direito a funerais completos, pois não entrarão jamais no Ebolo, reencarnar-se-ão sempre em filhos da mesma mãe ou de outras mulheres da comunidade. A verificação do Ekala é também necessária para orientação dos ritos de passagem segundo as qualidades desse princípio vital, pois nem todas as pessoas têm direito ao mesmo tipo de cerimônias, inclusive a honra da paramentação e exposição do corpo ou o enterro no cemitério, como é o caso dos "comedores de alma". (LeITe, 2008, p. 105)

As cerimônias funerárias comuns são processadas com cuidados especiais ao corpo pelos Abafoma. Os responsáveis pela preparação do corpo colocam uma quantidade de bebida alcoólica no interior do cadáver para retardar a sua decomposição. Se houver necessidade, coloca-se o corpo em um buraco durante um tempo numa posição em que possa expelir os dejetos e líquidos. Para evitar a rigidez do corpo, é preciso massagear as juntas com uma composição preparada por mulheres. Nela coloca-se manteiga vegetal retirada de uma árvore chamada Karite. Por ser muito utilizado, esse produto é encontrado facilmente nos mercados africanos.

O corpo é lavado com água e sabão, e então com uma infusão de água, folhas e limão. As unhas são aparadas, a barba é feita no caso dos homens, e os cabelos são trançados, no caso das mulheres. Finalmente, após ser colocada a roupa interior, o cadáver é vestido de maneira a demonstrar a posição social da pessoa. (LeITE, 2008, p. 106)

O enterro ocorre depois do cumprimento de todo um ritual. O corpo é levado da aldeia e em hipótese alguma deve retornar, pois entende-se "que a viagem em direção a Ebolo já teve início e o retorno do corpo à aldeia, nesse momento de separação dos princípios vitais, é altamente indesejável" (LeITE, 2008, p. 107). 
A cerimônia fúnebre entre o povo Agni segue alguns preceitos como colocar o morto com os pés na direção da aldeia e, para evitar que em caso de reencarnação o sujeito fique mudo, os pregos do ataúde são retirados. Caso o indivíduo seja um Efewoa, o corpo é colocado diretamente na terra e o ataúde só é colocado sobre a tumba depois de destruído. Vale ressaltar que, para garantir a hereditariedade desse Efewoa, Leite (2008) afirma que "uma folha específica é colocada sobre a cabeça do cadáver na tentativa de obrigar o Ekala do Efewoa a reencarnar no mesmo grupo familiar"'(p. 107).

O luto propriamente dito é composto por três fases. A primeira inicia-se logo após a morte e dura até o segundo dia depois do enterro, quando se prepara a refeição do terceiro dia, a chamada refeição comunitária. Essa fase do luto é extremamente delicada, já que "os processos de separação dos elementos vitais encontram-se em curso incipiente, a fase é dramática e prevê interdição do trabalho e jejum total" (LeITE, 2008, p. 108).

\section{AS MARCAS DA ANCESTRALIDADE EM NARRATIVAS LITERÁRIAS}

O romance Terra sonâmbula, de Mia Couto (1993), metaforiza a ruptura entre o mundo dos viventes e o dos ancestrais. Os personagens Muidinga e o velho Tuahir transitam por um cenário de mortos desprovidos dos rituais pertinentes à sua condição. No primeiro capítulo do livro, o narrador nos apresenta o ambiente que será palco de duas histórias: a primeira ficcionaliza a guerra civil vivenciada pelos moçambicanos entre 1976 e 1992; a segunda história, "Cadernos de Kindzu”, são a memória de um morto que não recebeu os preceitos necessários de sua passagem do mundo dos vivos para o dos ancestrais. No primeiro capítulo, "A estrada morta", o leitor toma contato com um Moçambique em dívida com seus ancestrais em decorrência de mortes provocadas por elementos externos. Leite (2008) define essa modalidade como negativa e se traduz em desordem, pois não é natural do ponto de vista da sociedade.

Naquele lugar, a guerra tinha morto a estrada. Pelos caminhos só as hienas se arrastavam, focinhando entre cinzas e poeiras. A paisagem se mestiçara de tristezas nunca vistas, em cores que se pegavam à 
boca. Eram cores sujas, tão sujas que tinham perdido toda a leveza, esquecidas da ousadia de levantar asas pelo azul. Aqui, o céu se tornara impossível. E os viventes se acostumaram ao chão, em resignada aprendizagem da morte. [...] Um velho e um menino vão seguindo pela estrada. Andam bambolentos como se caminhar fosse seu único serviço desde que nasceram. Vão para lá de nenhuma parte, dando o vindo por não ido, à espera do adiante. Fogem da guerra, dessa guerra que contaminara toda a terra. Vão na ilusão de, mais além, haver um refúgio tranquilo. Avançam descalços, suas vestes têm a mesma cor do caminho. O velho se chama Tuahir. É magro, parece ter perdido toda a substância. O jovem se chama Muidinga. Caminha à frente desde que saíra do campo de refugiados. Se nota nele um leve coxear, uma perna demorando mais que o passo. Vestígio da doença que, ainda há pouco, o arrastara quase até a morte. (Couto, 1993, p. 10-11)

O cenário de abertura nos informa o impasse e o desequilíbrio das forças vitais, mas não aquele pertinente ao instante da saída do sujeito do plano do visível para o plano dos ancestrais, quando está habilitado, ou para um espaço concernente ao tempo de reencarnação em geral no mesmo grupo familiar. Sendo assim, no primeiro caderno de Kindzu, intitulado "O tempo em que o mundo tinha a nossa idade", o personagem vive o impasse de estar entre os seus antepassados ou fugir e se transformar em outro homem. Nesse conflito, o único elemento capaz de orientá-lo é o adivinho:

Ele falava de uma viagem cujo único destino era o desejo de partir novamente. Essa viagem, porém, teria que seguir o respeito de seu conselho: eu deveria ir pelo mar, caminhar no último lábio da terra, onde a água faz sede e a areia não guarda nenhuma pegada. Eu que levasse o amuleto dos viajeiros e o guardasse em velha casca de ncuácua. E procurasse os confins onde os homens não amealham nenhuma lembrança. Para me livrar de ser seguido por meu pai eu não podia deixar sinais do meu percurso. Minha passagem se faria igual aos pássaros atravessando os poentes.

Segui o conselho dos anciãos evitando o assunto dos naparamas. O nosso adivinho se iria sentir magoado de não saber mexer em meus pedidos. Me calei, ouvidor de seus demorados conselhos.

- Te vais separar dos teus antepassados. Agora, tens de transformar num outro homem. 
O velho nganga atirou os ossinhos mágicos sobre a pele de gazela. Os ossos caíram todos numa linha, disciplinados.

- Está ver, todos linhados? Isso quer dizer: você é um homem de viagem. E aqui vejo água, vejo o mar. (Couto, 1993, p. 37)

O caminho possível na situação em que se encontra Kindzu é recorrer aos jogos divinatórios, pois o não cumprimento do funeral de seu pai deixa esse ente impossibilitado de repousar ou de adentrar o espaço sagrado. De acordo com Leite (2008), em seu estudo sobre os povos da África negra, 'o homem permanece em seu 'vestíbulo', carregando as bagagens levadas consigo nessa trajetória, sem poder juntar-se aos ancestrais" (p. 104). Cabe ressaltar que a ausência de funeral condizente com os preceitos tradicionais pode causar catástrofes, tragédias que assolam a comunidade. Estando Kindzu dentro de um cenário de guerra, a única saída é afastar-se de seus antepassados e, para isso, precisa ter a esperança de que seu pai não o perseguirá. $\mathrm{O}$ velho Taímo teve um funeral na água, mas no dia seguinte o mar transformou-se, como pode ser observado a seguir:

Cerimônia fúnebre foi na água, sepultado nas ondas. No dia seguinte, deu-se o que de imaginar nem ninguém se atreve: o mar todo secou, a água inteira desapareceu na porção de um instante. No lugar onde antes praiava o azul, ficou uma planície coberta de palmeiras. Cada uma se barrigava de frutos gordos, apetitosos, luzilhantes. Nem eram frutos, parecia eram cabaças de ouro, cada uma pesando mil riquezas. Os homens se lançaram nesse vale, correndo de catanas na mão, no antegozo daquela dádiva. Então se escutou uma voz que se multiabriu em ecos, parecia que cada palmeira se servia de infinitas bocas. Os homens ainda pararam, por brevidades. Aquela voz era de meu pai. Ele pedia que os homens ponderassem; aqueles eram frutos muito sagrados. Sua voz se ajoelhava clamando para que se poupassem as árvores: o destino do nosso mundo se sustentava em delicados fios. Bastava que um desses fios fosse cortado para que tudo entrasse em desordens e desgraças se sucedessem em desfile. O primeiro homem, então, perguntou à árvore: pó que és tão desumana? Só respondeu o silêncio. Nem mais se escutou nenhuma voz. De novo, a multidão se derramou sobre as palmeiras. Mas quando o primeiro fruto foi cortado, do golpe espirrou a imensa água e, em cantaratas, o mar se encheu de novo, afundando tudo e todos. (Couto, 1993, p. 23-24) 
O velho Taímo guarda características de divindade, mas, diante da desobediência dos homens, o que era benfeitoria oriunda do formato do funeral, transformou-se em tragédia. As imagens presentes na citação anterior, bem definidas por Kindzu ao longo da narrativa, só são recuperadas nos seus sonhos, quando os mortos costumam reivindicar seu funeral. Essa cobrança ocorre também por meio de aparições e manifestações negativas como doenças, esterilidade, epidemias, secas etc. Outra personagem vítima da situação excepcional é a viúva:

Certo foi minha mãe, após a viuvez, se enconchar, triste como um recanto escuro. Consultamos o feiticeiro para conhecermos o exato da morte de meu pai. Quem sabe era um falecimento sem validade, desses que pedem as mais devidas cerimônias? O feiticeiro confirmou o estranho daquela morte. Receitou-lhe: ela que construísse uma casa, bem afastada. Dentro dessa solitária residência ela deveria colocar o velho barco de meu pai, com seu mastro, sua tristonha vela. Seu dito, nosso feito. No ajunto de todos, empurramos o concho. Peso tão cheio nunca eu vi. O puxar do barco demorou todo o dia. Meu tio mais velho comandava os cantos, com sua voz, corpulenta. À noitita, junto da fogueira, me explicaram a tradição. Motivo do barco, dentro da casa: meu pai poderia regressar vindo do mar. E assim, todas as noites passei a levar para a casinha solitária uma panela cheia de comida. No dia seguinte, a panela estava vazia, raspadinha. (Couto, 1993, p. 24)

As palavras do feiticeiro são seguidas como orientação para apaziguar a relação entre os vivos e os antepassados. A força vital que emana da palavra, segundo Amadou Hampatê Bá (1982), é por excelência o grande agente ativo da magia africana, capaz de formular e reformular experiências advindas dos cantos rituais e nas fórmulas mágicas, portanto, a palavra é a materialização da cadência. Nessa cadência é que os ancestrais se movimentam, harmonizando e engendrando as forças mantenedoras das práticas sociais sustentadoras da tradição transmitida de geração a geração, pois as tipologias ancestrais se corporificam na linguagem de autores contemporâneos que valorizam a oralidade detentora das marcas da ancestralidade.

Contudo, o processo de transição deste mundo para o outro exige rituais específicos para aqueles considerados o elo entre os dois mundos. 
No quarto capítulo, "A lição de Siqueleto", o personagem Sequeleto ordena ao Muidinga que escreva seu nome na árvore; essa é uma forma de manter-se presente no mundo dos viventes:

Passa-lhe o punhal. No tronco Muidinga grava letra por letra o nome do velho. Ele queria aquela árvore para parteira de outros Siqueletos, em fecundação de si. Embevecido, o velho passava os dedos pela casca da árvore. E ele diz:

- Agora se podem ir embora. A aldeia vai continuar já meu nome está no sangue da árvore.

Então ele mete o dedo no ouvido, vai enfiando mais e mais fundo até que sentem o surdo som de qualquer coisa se estourando. $\mathrm{O}$ velho tira o dedo e um jorro de sangue repuxa da orelha. Ele se vai definhando, até se tornar do tamanho de uma semente. (Couto, 1993, p. 84)

O menino Muidinga, por não conhecer as regras estabelecidas nos códigos sociais acerca da morte, acredita que a passagem de Siqueleto seria o fim dos antepassados, das tradições. De acordo com Leite (2008), a saída dos mais velhos do mundo dos vivos não significa o fim. No livro A questão ancestral: África negra, ele afirma que a modalidade morte positiva é vivenciada pelos mais velhos, pois estes se encontram "mais perto das fontes sagradas de energia e do espaço ancestral" (p. 97). Transcreve-se aqui a passagem do romance de Couto (1993) em que é possível observar a afirmação de Leite (2008):

A morte do velho Siqueleto o seguia, em estado de dúvida. Não era o pouco falecimento do homem que lhe pesava. Não era o puro falecimento do homem que lhe pesava. Não nos vamos habituando mesmo ao nosso próprio desfecho? A gente vai chegando à morte como um rio desencorpa no mar: uma parte está nascendo e, simultânea, a outra já se assombra no sem-fim. Contudo, no falecimento de Siqueleto havia um espinho excrescente. Com ele todas as aldeias morriam. Os antepassados ficavam órfãos da terra, os vivos deixavam de ter lugar para eternizar as tradições. Não era apenas um homem, mas todo um mundo que desaparecia. (Couto, 1993, p. 103)

O término da existência visível provoca um desequilíbrio, uma desordem gerada pelo esfacelamento dos traços mantenedores da 
condição humana. No entanto, a desorganização oriunda da ruptura de equilíbrio gerada pela morte não caracteriza o apagamento total dos elementos vitais fundamentais para a explicação da imortalidade do homem e da construção da ancestralidade.

Do ponto de vista da sociedade, a morte se manifesta de duas formas: na velhice e a outra de maneira extraordinária, porém constatamos em ambas as situações as origens misteriosas do processo e seu desenrolar:

A morte que parece mais se aproximar de um conceito de consequência natural da existência visível é a ocorrida na velhice e dentro de certas regras sociais. É o caso da morte de um indivíduo idoso falecido após preencher critérios socialmente dados, como iniciação, formação de família numerosa permitindo descendência significativa e a existência de herdeiros legais, comportamento ético apropriado, dedicação ao trabalho, conhecimento respeitado na comunidade, posse de certos bens materiais etc. Uma pessoa nessas condições é considerada vitalmente mais 'forte', menos passível de ser atingida pelos efeitos da morte em virtude de ações mágicas de homens, divindades, ancestrais ou outras forças irredutíveis da natureza. (LeITE, 2008, p. 96)

A concepção de positividade da morte ligada aos mais velhos significa que, por estarem mais próximos das fontes sagradas de energia e do espaço ancestral, lugar que deverão ocupar futuramente, tornam-se seres escolhidos e, na perspectiva da sociedade, o mais velho constitui um elo bastante significativo entre as pessoas e os ancestrais. Tendo em vista que os ancestrais são uma ligação entre os homens e o sagrado, a problemática que envolve a formação de uma comunicabilidade entre esses seres especiais pode ser preenchida pelos idosos. Dessa forma, pode-se afirmar que um velho africano é quase um ancestral vivo.

Em Mãe, materno mar, de Boaventura Cardoso (2001), as imagens referentes ao processo que caracteriza a morte são apresentadas ao leitor com um discurso de fundo filosófico religioso:

- E no princípio era a Terra. Da Terra viemos e um dia a ela voltaremos. É essa a lei da vida de todos os vivos. [...] É, pois chegada a hora destes quatro irmãos, Francisco, António, Domingos e Kinbulu, regressarem ao ponto de partida, à Terra donde nasceram. Mas 
esse regresso à Terra, embora nos pareça definitivo e irreversível, é um regresso fecundante, ativo, pois os corpos desses nossos quatro irmãos quando forem depositados lá em baixo, hão de fecundar esta Terra que pisamos. E então a Terra terá mais vida, ela será sempre renovada e rejuvenescida. Na prática, este princípio vital e sagrado significará que os exemplos de honestidade, de verticalidade, de integridade moral desses nossos quatro irmãos serão seguidos por todos nós que aqui vivemos ou que estamos em trânsito para outras paragens, não importam as diferenças étnicas, religiosas ou culturais que nos possam separar. (CARDOSO, 2001, p. 59-60)

Com uma linguagem pautada em elementos que remetem à filosofia religiosa do destino humano, guardadas as devidas proporções, a percepção valorativa de repouso dos viventes se assemelha àquela pensada por Leite (2008) no livro A questão ancestral: África negra. Para saudar devidamente a passagem de seu ente querido, os familiares de Kinbulu sacrificam três galinhas e cantam:

A família de Kinbulu ainda sacrificou três galinhas brancas sobre a campa do recém-defunto para purificar a sua alma. Dançando em volta da campa que os parentes de Kunbulu cantaram assim:

Eh! Kinbulu! Aí para onde tu vais

não te esqueças de nós

Olha pelas nossas vidas, Kinbulu!

Aí para onde tu vais, mano Kinbulu não é o santuário dos nossos antepassados?

Então, mano Kinbulu, quando chegares lá cumprimenta os que já se foram deste mundo

Eh! Kinbulu! Aí para onde tu vais não é a morada de Deus?

Então pede-Lhe que olhe por nós

Que nos dê saúde e muita paz.

(CARDoso, 2001, p. 60-61)

A confirmação do fim da existência no plano terrestre leva a comunidade a se organizar para dar continuidade à existência do indivíduo no mundo dos ancestrais. Dito isso, confirma-se que é fundamental elaborar o processo de passagem por meio das cerimônias funerais, já que nenhum indivíduo poderá transitar de um mundo para 
outro sem efetuar o ritual funeral completo. Os efeitos maléficos da ausência do cumprimento do ritual podem ser percebidos de diversas formas, pois "aqueles que não recebem funerais indicam das mais variadas formas a necessidade de sua efetivação, através de sonhos, aparições e mesmo manifestações negativas, como doenças, esterilidade, epidemias, secas etc.” (LeITE, 2008, p. 104).

Em Mãe, materno mar, percebe-se uma prática recorrente após a proibição do sacrifício humano. A família de Kinbulu mata três galinhas para saudar a passagem para o outro mundo. Com a proibição formalizada pelas comunidades, o sangue animal passa a ser usado nos rituais em substituição ao sangue humano. Ocorreu uma superposição, pois os animais sacrificados dentro de preceitos específicos, de acordo com Leite (2008), "passaram a representar o homem na imolação ritual" (p. 98).

No funeral dos quatro homens, houve várias situações conflituosas, porque as mortes não aconteceram por causas naturais, mas provocadas após uma briga generalizada que atingiu todo o comboio. A narrativa de Mãe, materno mar se desenvolve dentro de um comboio que sai de Malange com destino a Luanda. No decorrer da viagem, que metaforiza um período da história de Angola, os passageiros inconformados com os problemas que vivenciaram durante o trajeto, já que o comboio parou diversas vezes por falta de manutenção, promovem uma confusão generalizada. O desequilíbrio social reflete-se na forma como a Terra recebe seus mortos:

Quando todo o povo se começava a retirar do cemitério, no calor de tão profunda e sentida dor, se ouviu um estranho barulho que vinha do fundo das quatro covas. Eé! Eé! Eé! As pessoas se precipitaram logo, começaram a fugir, tat'é! Aiué! Manecas foi dos primeiros a saltar o muro rústico do cemitério, pai da noiva pisou em terreno falso e resvalou para dentro de uma cova! Ngafu é! Chefe da Estação tinha o corpo todo arranhado por ter caído numa trepadeira espinhosa, os integrantes da banda de música tinham se desembaraçado dos seus incômodos instrumentos, líderes religiosos fugiam esquecidos dos seus fiéis, duas senhoras grávidas permaneciam deitadas e aos berros, quem que corria mais rápido não eram então os jovens? Em pouco tempo o cemitério ficara quase deserto. Só se viam deitados no chão, de barriga para baixo, as duas senhoras grávidas, gemen- 
do e, dispersos, mais de vinte velhos quase inanimados. Entretanto, o estranho barulho continuava a fazer-se ouvir, enquanto o pai da noiva, dentro da cova, esbracejava e prometia uma boa nota a quem lhe tirasse daquele fatídico buraco! Uá! E Ti Lucas e o rapazito não tinham fugido do cemitério. [...] E o ceguinho, impávido e sereno, se agachou e com a mão direita fez no chão uma cruz, e então a Terra se sossegou repousada. [...] aquele estranho barulho era a Terra a ruminar depois de ter engolido as quatro sementes. (CARDOso, 2001, $\mathrm{p}, 61-62)$

A constatação do fim da vida no plano terrestre leva a sociedade a se preparar para transportar o sujeito ao mundo dos ancestrais, razão pela qual as cerimônias funerárias são importantíssimas. Segundo Leite (2008), não existe qualquer abertura para um indivíduo que não recebeu os preceitos necessários para ocupar seu lugar no mundo dos ancestrais, logo, na ausência de um funeral compatível com o sujeito, este ficará vagando e cobrando de seus entes queridos de diversas formas esse ritual para que possa repousar. Na segunda parte de Mãe, materno mar, o narrador nos conta a seguinte história:

Se falava mesmo de um esqueleto que vinha todas as noites a Aldeia Formosa, passeava, ih?!, de cigarro na boca!, mam'é!, olhos dele luminosos pareciam eram as brasas incandescentes, quando andava fazia um estranho barulho, um robor construído em ferro velho, se falava que esse esqueleto não era então de um morto desaparecido em as traiçoeiras águas?, Que, por isso, não tinha tido o funeral que ele agora vinha de reclamar, mam'etu ééé As almas do outro mundo saindo dos seus esconsos lugares! (CARDOSo, 2001, p. 146-147)

O trecho acima nos remete à explicação fornecida por Leite (2008) acerca daqueles defuntos que não receberam o devido funeral. Com uma linguagem cômica, Cardoso (2001) expõe em sua obra uma experiência que denota a falta de cumprimento das regras básicas para garantir o descanso daquele que saiu do espaço dos vivos. Outra imagem semelhante evidencia-se na narrativa de A morte de velho Kipacaça, do livro de contos com o mesmo nome. O narrador nos fornece várias pistas que nos faz recorrer mais uma vez aos preceitos estabelecidos por Leite (2008). A primeira diz respeito ao sonho premonitório que Mana Teresa teve: 
Mana Teresa gostava de ver assim marido dela contente, alegre, mas nesse dia estava desquieta por causa do sonho que tivera. Parecia estar ngó atenta, mas estava distraída. Mana Teresa olhava no marido dela e tinha impressão que o fazia pela última vez. Para além do sonho que tivera, durante a noite ouvira perfeitamente a coruja cantar. - Estou preocupada, Kipacaça ... - Mana Teresa, voz embargada.

- Teté deixa ngó de pensar assim. Eu vou e daqui tem dois ou três dias estou a vir ngó. (CARDOSO, 2004, p. 46-47)

A esposa do velho Kipacaça sentiu o coração apertado, mas não pôde impedir que seu companheiro fizesse a sua penúltima viagem, pois a última seria a passagem para o mundo dos ancestrais. Na tradição daquele grupo, significa azar quando um caçador vai e não volta da caça:

- Ngana Kapiapia falou mbora certo. Eh. Na nossa tradição é azar quando um caçador vai ngó na caça e não volta da caça. Se caçador morre em qualquer parte e corpo dele caçador não está aparecer para lhe entregar no Pupangombe, eh! eh! eh!, a alma dele fica ngó sempre a passear, a passear e alma dele nos aparece assim um dia a nos pedir contas! (CARDOSO, 2004, p. 38)

$\mathrm{Na}$ ausência do corpo e de um corpo importante para a comunidade, pois ele era um caçador, faz-se um komba diferente: "komba de Kipacaça era komba diferente. Não teve funeral, nem sequer levaram ngó cabra para a sepultura. Tinha ainda gente esperançada no reaparecimento do Velho Kipacaça" (Cardoso, 2004, p. 56). No entanto, o retorno do velho não se dá de forma tradicional, mas sim, esplendorosa e violenta, pois a fogueira grande destrói todas as cubatas. O velho Kipacaça vem participar de seu komba:

Inesperadamente surge fogueira grande se alastrando [...]. Tem fogueira e animais vindo na direção do Bango ya Coma, no komba do Velho Kipacaça. Vem vindo galopante, fogorosamente: a todos estão a vir assistir no komba do grande caçador. Mas gente do komba está tentar fugir. Mas já não dá para fugir longe. Vem vindo: fogueira e animais. É cerco: a queimada. Eh! Nisso no meio da queimada se vê homem em cima de pacaça de tamanho nunca visto. Tinha tamanho gigante, chifres dourados, peito debruado, patas luzentes: 
a pacaça. Eh! Quando a pacaça está próxima todo mundo, atônito, Ehé! Ehé! Ehé! Mam'é! Tem na volta dele auréola luzidia. Pacaça se imobiliza, se agacha e Velho Kipacaça, ar imponente, triunfante: desce. (CARDoso, 2004, p. 62-63)

A dimensão das relações do Velho Kipacaça se caracteriza pelo número de pessoas em seu komba e pela quantidade de presentes recebidos. De acordo com Leite (2008), as oferendas são uma prática nos rituais funerais, mas se o ancestral tiver essência histórica recebe presentes especiais, visto que um caçador ocupa lugar de destaque em todas as comunidades africanas, especialmente por se tratar de um que salvou diversas vidas e nunca deixou de cumprir seus compromissos na comunidade:

A animação prossegue. Gente: vindo. Pelo número de gente que estava no komba se podia avaliar fama do Velho Kipacaça. Além disso o finado também tinha muitas amizades. Gente que vem não vem só assim com mãos cheias de nada. Fubá, óleo de palma, galinhas, porcos, cabritos até alguns bois: na oferenda. Os assados, canjicada, funge com kimaquende punham as mulheres numa azáfama infernal e fogante e fumarenta. (CARDOSO, 2004, p. 60)

No entanto, a morte decorrente do sacrifício ritualístico também é positivada pela sociedade, exceto os casos destoantes das práticas vigentes que busca estabelecer um vínculo significativo com o sagrado. O conto "Seiva", de Fragata de Morais (2000), reforça a ideia de morte em sacrifício. O primeiro ritual trata de uma prática recorrente de quinze em quinze anos para garantir a existência do grupo. A narrativa conta a história de um sacrifício de fertilidade preparado por mulheres que utilizam uma cobra no ritual e uma mulher mais velha tem a função de desvirginar a moça com o dedo:

O acontecimento repetia-se cada quinze anos, o espaço de uma geração, desde os tempos que a memória coletiva o retinha. [...] Empinada por completo, a cobra levitou para cima do ventre da rapariga. $\mathrm{O}$ bater das palmas ganhou vigor renovado e a floresta preparou-se para o manifestar da vida. Em gesto descontrolado e até brusco, a serpente tateou a língua sedosa pelos seios retesados, passeou o corpo escorregadio no baixo ventre, licenciosa entre as coxas. E 
quando o corpo da jovem pairou no ar com ela enroscada à volta, o terrível grito ululante das mulheres explodiu reverberante na selva maravilhada. $\mathrm{O}$ surdo e frenético bater das palmas foi interrompido bruscamente, a cobra desenvencilhou-se da rapariga, e apressada, trepou pela estaca para desaparecer no templo. [...] Na clareira, todas as mulheres rastejavam contorcionadas como se de serpentes se tratassem. Uma, a que besuntara a jovem com a substância oleaginosa, em gesto seguro e determinado, enfiou dois dedos calejados pela vagina da rapariga e desflorou-a seca, mas eficientemente. Com um grito de dor, acordou do estupor em que se encontrava e tomou consciência da mulher mais velha a lamber o sangue virginal nos dedos. Desmaiou porque soube que fora a escolhida e qual seria seu desordenado futuro. (MoraIs, 2000, p. 25-26)

A segunda cena, em um primeiro momento, parece romper com os preceitos estabelecidos pelo grupo, mas no desfecho da trama detecta-se que toda a preparação para o encontro dos amantes fora acompanhado pelas mulheres que tinham a incumbência de fazer o ritual de fertilidade:

Cuidadoso e sensato, não se mostrou apressado. Acariciou-lhe o rosto e Mbuta baixou os olhos, sorrindo mais para si mesma do que para ele. Já imaginara o que seria perder a virgindade em condições normais, não dois dedos calejados, mas sim a dor física do amor a sobrepor-se ao prazer. [...] Jorge Torres, atordoado pela voluptuosidade inesperada da namorada, logo se recompôs. Apertou-a com paixão e preparou-se para o amor. Com frenesi conseguiu desnudar-se. [...] Quanto a Mbuta, já há algum tempo que partira da casa da lenha, só o corpo restara, cada vez mais abraçado a Jorge. [...] Sua essência descia enroscada pelo poste na clareira, ao ritmo do bater abafado das mãos e dos pés das mulheres, em seus cânticos de fertilidade. [...] Silenciosa, feita serpente maior do que a jiboia, foi apertando os elos pelo corpo do amado que, de olhos cerrados e arfando, gozava o amor e a entrega, sem notar que a asfixia que sentia não se devia ao êxtase do prazer fulgurante e ritmado, mas sim ao aperto premente da cobra em si enroscada. [...] Quando sentiu o ar faltar-lhe por completo, no momento excruciante do orgasmo, já roxo, seus olhos esbugalhados viram a enorme cabeça da jiboia a olhá-lo, língua bifurcada silvante. [...] Despedindo-se no último beijo de amor, sua cabeça tombou por fim para o lado, o corpo inanimado 
amassado. [...] A serpente desenroscou-se e rastejou silenciosa para o mato, desaparecendo. (Morais, 2000, p. 34-35)

Dessa forma, o sacrifício poderá ser colocado em um primeiro plano "como uma proposição de energias vitais e sua canalização às instâncias divinas ou ancestrais, constituindo-se em técnica de comunicação com esse universo e de reversão simbólica à fonte originária dos princípios configuradores da vida" (Leite, 2008, p. 97). Nesse sentido, a morte ocorrida durante o sacrifício ou em decorrência deste significa benefício para a coletividade, pois mantêm acesas, "por um lado, as leis da natureza e, por outro, as da ancestralidade e sua continuidade". No conto "O caçador", Morais (2000) apresenta um ritual de circuncisão masculina. Esse ritual de passagem pode levar o indivíduo à morte, mas do ponto de vista da sociedade esse passamento é entendido como positivo, pois é o cumprimento de uma prática comum, como podemos perceber no trecho a seguir:

Embora lhe fosse um entendimento natural, por vezes tinha relutância em aceitar, entender, que a morte tivesse que ser onipresente em cada intenção, concreta ou abstratamente. [...] Quando Ovindanda, na Mucanda, vira alguns de seus companheiros morrerem porque as infecções produzidas não aguentaram os enfraquecidos corpos. A mesma faca, que a uns cortara e lançara preparados para uma vida nova e novo mundo, a outros determinara que houvesse que partir, o caminho meio percorrido, para as colinas viajantes que o cágado carrega na carapaça. [...]. As leis que assim o ditavam ele as conhecia e temia, eram, por um lado, as leias da natureza e, por outro, as da ancestralidade e da continuidade. Portanto, aceitava-as inquestionavelmente. Mesmo havendo um medo desconhecido que, à revelia, invadia-lhe a alma, por parecerem, às vezes, não aquânimes e harmoniosas ou desproporcionadas. (MorAIs, 2000, p. 72)

Essa experiência desenvolvida no particular - com o corpo do indivíduo - para beneficiar a coletividade se caracteriza pela devolução de energia divina contida no sangue gerador da continuidade e renovação do ancestral. Sendo assim, "o sangue ancestral, legado juntamente com a terra, tem como símbolo vivo o indivíduo e a coletividade, revertendo aos ancestrais através do sacrifício, cria um circuito" (LeITE, 2008, p. 97), fortalecedor da aliança entre o homem e o ancestral. 
O personagem Carlos Macaia do conto "O caçador", de Morais (2000), recebe por meio de sonhos uma mensagem premonitória que ele desconhece a origem, tendo em vista que nascera em Luanda, área urbana, e não sabia a origem de seus bisavós. A falta de registro da história do casal Macaia deixa-os vulneráveis até o momento da sua chegada ao mundo dos ancestrais, quando encontra sua única filha do primeiro casamento e sua primeira mulher que fez a passagem no ato do nascimento da menina:

De fato. Pressinto que alguém deseja comunicar-me mas é só isso. Nada mais que um pressentimento, uma intuição. Deveremos falar com os nossos pais para saber se no passado terá havido algum caçador nas nossas famílias. [...]. Caçador? E da altura que referes, do início do século, ou até talvez do fim do século passado? [...] Quem? Nem os teus bisavós conheces!... E os meus?, riu Jumila. [...] Pelo menos creio que, até aos meus avós paternos sou kikongo, e antes disso também. Por que raios apareço no sonho como um ambó? Isso seria mais lá para os lados da tua família, que tem ramos sulinos na sua maioria. [...] Esta questão permaneceu para sempre. [...] No dia em que morreu, desfalecido na velhice, Carlos Macaia, partiu para o Além correndo pensamentos, não da longa prole que deixava com a sua segunda e desamada mulher, Matilde, mas que em breve iria finalmente saborear o longo desabraço que a vida lhe propusera, com a filha única do seu primeiro amor, que nascera morta, e à qual Jumila não sobrevivera. Ambas o esperavam alegremente. (MoRAIS, 2000, p. 78)

O afastamento do mundo dos vivos de caráter negativo diz respeito àquelas mortes súbitas, oriundas de acidente, suicídio ou doenças provocadas por algum mal. Nesses casos, entende-se que houve um descuido do humano com seu princípio vital. Essas mortes estão ligadas às negligências cometidas pelos sujeitos em relação a seu Ekala. Em geral, esse tipo de morte ocorre por transgressão de preceitos como "ausência de sacrifícios, práticas de relações sexuais não seguidas de um período de purificação, emanações consideradas negativas oriundas de mulheres em período menstrual" (LeITE, 2008, p. 99).

No conto "A revelação", do livro Contos de morte, de Pepetela (2008), a personagem comete suicídio: 
Os gritos vinham da esquerda. O moleque atravessou a cerca, entrou na rua e na luz do Sol. Dirigiu-se à casa para que concorriam. Lá chegando, percebeu imediatamente o que se passara, Mariana morrera.

Se matou. Uma facada mesmo no coração. (p. 27-28)

Já no conto "A mandioca de feitiço", a morte ocorre depois de o personagem comer uma mandioca enfeitiçada. Vale ressaltar que o nativo reconhece o feitiço ao ver os panos vermelhos amarrados nas plantas, mas o branco não acredita e come com todo prazer as mandiocas que só deveriam ser tocadas pelos donos da plantação:

- Tens a certeza que esta mandioca não tem veneno?

- Não tem. Mas tem feitiço. É pior.

- Deixa-te disso.

- Esses panos vermelhos que se amarram em cima são para avisar. Essa lavra foi enfeitiçada. Só os donos podem tirar.

- Essas crenças são pagãs, nem devias dizer isso. É pecado.

[...] A meio da noite, Ndozi foi acordado pelos gemidos do companheiro [...] - faz alguma coisa, porra, pá.

- Fazer o quê? - disse Ndozi. - Não há nada a fazer. É feitiço.

- Só a Senhora da Saúde me pode valer, ela é muito mais forte que qualquer feitiço - ainda disse Faustino no meio dos gemidos. - Ai valei-me, Senhora da Saúde.

Não lhe valeu. Ndozi ficou ao lado dele, assistindo impotente e pesaroso à agonia. De manhã, usou o facão de Faustino para cavar uma sepultura no meio do mato. E lá ficou para sempre o ladrão de Abaças. No mais completo segredo. (Pepetela, 2008, p. 65-66)

No conto "Mondlane, o criador", de Paulina Chiziane (2013), detecta-se a imagem de um ancestral de essência histórica: Eduardo Mondlane foi um dos fundadores e primeiro presidente da Frente de Libertação de Moçambique (FRELIMO), a organização que lutou pela independência de Moçambique do domínio colonial português. $\mathrm{O}$ dia de sua morte é celebrado como o dia dos heróis moçambicanos. A narrativa metaforiza o fato histórico e traça um parâmetro entre $o$ mundo dos vivos e o dos ancestrais. A personagem que circula entre os dois espaços o faz por meio dos sonhos que lhe parece realidade: 
No sonho, transportara uma cobra medonha, muito mais pesada que as suas forças. Mas se era sonho, por que é que o corpo me dói como se fosse realidade? Seria ele, na vida real, capaz de semelhante sacrifício? (Chiziane, 2013, p. 46)

As manifestações em sonhos, por um lado, são uma forma de os mortos se comunicarem com os vivos. Por outro lado, o menino constitui-se num elo entre os dois espaços, mas não entende bem qual a sua função naquele contexto:

Os antepassados the chamam Chivambo, o rei. Aqui começa a confusão na cabeça do menino, que o leva a este monólogo. Dizem que fui rei, lá nesses tempos mortos. Que tipo de rei? Rei morto? Rei mártir? Mas que grande mania têm estes antepassados de definir destinos, códigos, mistérios, no nome de um sujeito! A minha mãe acredita piamente nessa loucura e passa a vida a chamar-me rei, reizinho, que até acabo acreditando nela. (Chiziane, 2013, p. 49)

A força com que a ancestralidade define os destinos dos vivos reforça a ideia da dinâmica cultural em uma África distinta daquela pensada pela mentalidade ocidental. Dessa forma, recuperar por meio da linguagem, nas obras contemporâneas, a questão da existência e da indestrutibilidade de um princípio vital extremamente diferenciador como a ancestralidade é uma tarefa que o discurso literário vem desenvolvendo com muita propriedade.

\section{A linguagem QUE RESGATA A ANCESTRALIDADE}

A linguagem de Terra sonâmbula, de Mia Couto (1993), transita entre a forma culta e a coloquial para planificar, no espaço literário, características denunciatórias do descompasso por que passa Moçambique, mas também estabelece o viés discursivo valorativo de uma prosa poética revigoradora dos elementos que sustentam uma sabedoria ancestral. Em Terra sonâmbula, a sintaxe e o léxico de suas enunciações repousam ora num português oral, ora em um português mais formal. Sendo assim, quando a narrativa trata dos cadernos de Kindzu, detectamos a fala do grupo que criou sua forma peculiar de se expressar, desvinculada daquela valorizada pelos padrões de 
Portugal. A autora valoriza um aspecto bastante significativo na cultura moçambicana: os provérbios.

Em contrapartida, o livro A morte do velho Kipacaça, de Boaventura Cardoso (2004), valoriza a forma local de se expressar. Com uma musicalidade peculiar à do contador de história, o narrador desse conto, que dá nome ao livro, teatraliza a experiência da morte para explicar e cumprir o funeral do caçador. $\mathrm{O}$ enunciado do conto transmite com propriedade o desempenho de um momento único naquele grupo, o komba, logo, uma prática utilitária e corrente é recuperada pela memória do escritor com o intuito de fazer circular outros saberes.

$\mathrm{Na}$ qualidade de grande metáfora da vida, a literatura constitui-se num caminho para o escritor fundar sua dicção ficcional e buscar recuperar a ternura da condição humana, nos seus múltiplos e variados contornos, por meio da palavra literária que busca estabelecer uma cumplicidade com o "local da cultura". Num encontro entre o presente e o passado, ainda que imaginários, o escritor promove discursivamente o que Bhabha (1998) define como o trabalho fronteiriço resultante do estudo ou do resgate da cultura. Com um desempenho que abarca tempos memoráveis, Fragata de Morais (2000), Pepetela (2008) e Paulina Chiziane (2013) também registram numa linguagem compreendida como diálogo entre o mundo dos vivos e dos ancestrais, e do diálogo compreendido como espaço de potência exercida no tempo narrativo, as marcas da ancestralidade.

O enunciado, ao privilegiar experiências passadas, oriundas de um cotidiano repleto de imagens legitimadoras das práticas sociais recorrentes nas sociedades negro-africanas deixa transparecer 0 desequilíbrio provocado pela ausência de ritos adequados na legitimação da ancestralidade. A matéria sustentadora do discurso literário dos escritores analisados aqui repousa sob um substrato imaginário que busca reconfigurar a imagem do ancestral, pois a narração inscreve os fatos num tempo que permite reatualizar aquilo não cumprido. Sarlo (2007) afirma que

a narração da experiência está unida ao corpo e à voz, a uma presença real do sujeito na cena do passado. [...] A narração inscreve a experiência numa temporalidade que não é a de seu acontecer [...], mas a de sua lembrança. A narração também funda uma tempora- 
lidade, que a cada repetição e a cada variante torna a se atualizar. (p. 24-25)

A enunciação recompõe práticas silenciadas, pois só os pares têm acesso aos rituais e conhecem seus significados. Em Mãe, materno mar, Cardoso (2001), com um discurso cômico, explicita costumes, valorizando os detalhes, as originalidades, a exceção à regra e as curiosidades subentendidas em contextos específicos. O cômico é uma marca da escrita desse autor que usa o exagero como forma de expor situações de conflitos, de imagem a imagem. Bergson (2001) afirma que "o exagero é cômico quando prolongado e, sobretudo, quando sistemático: é então que aparece como um procedimento de transposição" (p. 93).

O cômico transita entre a exageração e a degradação. Esse artifício linguístico marca significativamente tanto Mãe, materno mar e A morte do velho Kipacaça, de Boaventura Cardoso (2001; 2004), quanto o conto "A seiva", do livro Momento de ilusão, de Fragata de Morais (2000). Em oposição ao discurso cômico desses autores, encontra-se a perspectiva dramática da linguagem dos demais autores aqui estudados. Nessas narrativas, eles elevam experiências trágicas ao extremo, contraditoriamente, a palavra que libera o riso também o aprisiona e expõe cenas de violência como aquelas presentes no conto "O caixão do molhado", do livro Contos de morte, de Pepetela (2008), quando a personagem Mariana, no primeiro dia de casada, morre de susto ao se deparar com um caixão embaixo da cama do casal:

Mariana foi a enterrar no caixão que o desconsolado marido encomendara dez anos antes para si próprio. [...] Vale a pena acrescentar que, depois de enterrar duas esposas, e uma delas com menos de um dia de casamento, sô Belarmino ultrapassa definitivamente o trauma de criança e disse para si próprio, que se lixe se passar pela cidade de cara descoberta, mas outro caixão é que não arranjo, pois tanta previdência pode não ser prudência. (PePETELA, 2008, p. 48)

Com uma linguagem estilizada, Mia Couto (1993) encena mimeticamente situações que remontam a guerra civil em Moçambique. Em um cenário de homens famintos, evocando os antepassados por acidentes com navios repletos de alimentos, evidencia-se a força dos rituais: 
Desde então, a situação só piorou, pois, consoante o secretário do Administrador, a população não se comporta civilmente na presença da fome. Muita gente insistia agora em voltar ao tal navio, pois lá sobrava comida que daria para salvar filhos, mães e uma africanidade de parentes. [...] Era esta a razão por que se escutavam tambores consecutivos, rezas obscurantistas em todas as praias, clamando aos antepassados para outros navios se afundarem, suas cargas se espalharem e desaguarem nas mãos dos famintos. (p. 69-70)

O deslocamento de práticas ritualísticas das sociedades negro-africanas para o plano literário constitui-se numa técnica artística moderna. Esse deslocamento está muito próximo do que tradicionalmente chamamos estranhamento ou desvio. Sobre o assunto, Vitor Manuel de Aguiar e Silva (2007) afirma:

O texto é sempre, sob modalidades várias, um intercâmbio discursivo, uma tessitura polifônica na qual confluem, se entrecruzam, se metamorfoseiam, se corroboram ou se contestam outros textos, outras vozes e outras consciências. (p. 625)

Nessa perspectiva, a literatura coloca em cheque a visão da história, da antropologia, da memória, da oralidade, mas também estabelece com essas áreas do conhecimento um profícuo diálogo, quando encontram nos substratos culturais referências sustentadoras das marcas da ancestralidade na narrativa. Do ponto de vista artístico, esse modo de resgatar práticas milenares, em narrativas literárias, representa uma forma de desarrumar, inverter, interromper a normalidade cotidiana e chamar a atenção para alguma coisa não dita, mas interdita por mudanças nos códigos sociais.

\section{THE MARKS OF THE ANCESTRY OF CONTEMPORARY AUTHORS WRINTING IN AFRICAN LITERATURES IN PORTUGUESE}

\section{ABSTRACT}

This study critically analysis traces of ancestrality in African narratives of Portuguese-language writers. The corpus of analysis comprises the following works: Terra sonâmbula (1993), by Mia Couto, Momento de ilusão (2000), by Fragata de Morais; Mãe, materno mar (2001) and A morte do velho Kipacaça 
(2004), by Boaventura Cardoso; Contos de morte (2008), by Pepetela and As andorinhas (2013), by Paulina Chiziane. The typological vision of Leite about the notion of ancestrality in the work A questão ancestral: África negra (2008) as well as studies on memory, orality and Literary Theory are used to support the analysis proposed in this study.

KEY WORDS: Africa, ancestry, divinity, oralit, memory, fiction.

\section{LAS MARCAS DE LOS ANTEPASADOS EN LA ESCRITURA DE AUTORES}

CONTEMPORÁNEOS DE LAS LITERATURAS AFRICANAS DE LENGUA PORTUGUESA

\section{RESUMEN}

El presente trabajo propone una lectura crítica de las marcas de la ascendencia familiar en las narrativas africanas de lengua portuguesa. El corpus escogido para el análisis se compone de Terra sonâmbula (1993), de Mia Couto, Momento de ilusão (2000), de Fragata de Morais; Mãe, materno mar (2001) y A morte do velho Kipacaça (2004), ambos de Boaventura Cardoso; Contos de morte (2008), de Pepetela y As andorinhas (2013), de Paulina Chiziane. La tipología de Leite sobre la noción de ascendencia en la obra $A$ questão ancestral: África negra (2008), así como estudios sobre memoria, oralidad y del área de la Teoría de la Literatura son usados para dar la base al análisis propuesto en este estudio.

Palabras Clave: África, ascendencia, divinidad, oralidad, memoria y ficción.

\section{Nota}

1 De acordo com Leite (2008, p. 66), na comunidade Agni da Costa do Marfim, a criança recebe um nome referente ao dia de seu nascimento, que não é atribuído ao indivíduo como manifestação exterior, mas ao seu Ekala, o princípio imortal de individualização do homem e de seu destino.

\section{REFERÊNCIAS}

BÂ, Amadou Hampâté. Tradição oral. 1982. Disponível em: <http://marciadib. blogspot.com.br/2009/06/tradicao-oral-amadou-hampate-ba.html>. Acesso em: 26 abr. 2014. 
Bergson, Henri. O riso: ensaio sobre a significação da comicidade. São Paulo: Martins Fontes, 2001.

Bнавна, Romi. K. O local da cultura. Belo Horizonte: UFMG, 1998.

CArdoso, Boaventura da Silva. Mãe, materno mar. Luanda: Chá de Caxinde, 2001 . 2004.

. A morte do velho Kipacaça. Luanda: União dos Escritores Angolanos,

Chiziane, Paulina. As andorinhas. Belo Horizonte: Nandyala, 2013.

Couto, Mia. Terra sonâmbula. Rio de Janeiro: Record/Altaya, 1993.

LeIte, Ana Mafalda. Oralidades e escritas nas literaturas africanas. Lisboa: Colibri, 1998.

Leite, Fabio Rubens da Rocha. A questão ancestral: África negra. São Paulo: Palas Athena/Casa das Áfricas, 2008.

Morais, Fragata de. Momento de ilusão. Porto: Campo das Letras, 2000.

Pepetela. Contos de morte. Lisboa: Nelson de Matos, 2008.

Sarlo, Beatriz. Cultura da memória e guinada subjetiva. São Paulo: Companhia das Letras; Belo Horizonte: UFMG, 2007.

Silva, Vítor Manuel de Aguiar e. Teoria da literatura. Coimbra: Almedina, 2007.

Recebido em 9 de maio de 2014

Aprovado em 15 de junho de 2014 